\title{
Factors Contributing to Communication Apprehension among Pre-University Students
}

\author{
Amelia Alfred Tom \\ Universiti Teknologi MARA \\ Email: ameliaalfred@sarawak.uitm.edu.my \\ Aiza Johari \\ Universiti Teknologi MARA \\ Email: aiza@sarawak.uitm.edu.my \\ Awang Rozaimi \\ Universiti Teknologi MARA \\ Email: awgrozaimi@sarawak.uitm.edu.my \\ Siti Huzaimah \\ Universiti Teknologi MARA \\ Email: huzaimahs@sarawak.uitm.edu.my
}

\section{Doi:10.5901/ajis.2013.v2n8p665}

\section{Abstract}

This paper intends to investigate factors which may contribute to communication apprehension among English language learners in Sarawak, Malaysia. 49 pre-university students under a special programme called 'Changing the Destiny of Our People' (Mengubah Destini Anak Bangsa) participated in the study. They were chosen as their English course puts a heavy emphasis on speaking skills. Additionally, the course also expects the students to participate in both individual and group speaking tests. The data were gathered via a questionnaire and semi-structured interview. Generally, it was found that the learners disliked group discussions and were uncomfortable speaking in English. The learners were seemingly unprepared and unaware of the presentation organization. They were also found to display nervousness when asked to present in front of their classmates from the opposite gender. Finally, the learners were also not confident with their ability to pronounce English words correctly.

\section{Introduction}

Despite the fact that English is a second language in Malaysia, many students from rural areas in Sarawak view English as a foreign language which is spoken only during language lessons. When they enter the university, these learners often struggle with difficulties in speaking English. However, English is the medium of instruction in most public universities in Malaysia, such as UiTM, and also a pre-requisite in most jobs, thus making it necessary for the students to learn and master the language, especially for communicative purposes. Yet, many students are found to fear the thought of speaking in English and seem to display signs of being ill at ease when communicating in the language.

\section{Significance of the Study}

This study will be of interest to English language students due to the fact that anxiety or apprehension may negatively affect language learning (Phillips, 1992; Campbell \& Ortiz, 1991). This study is also significant to language educators, curriculum designers and policy makers as it provides insights into the issue of communication and language anxiety. This may help the educators and policy makers to design courses which will be able to assist the students in overcoming their fear of speaking in a second or foreign language. As such, this study may help language educators to understand the types of communicative activities that may cause communication apprehension among pre-university students. Hence, this will enable the educators to find practical means in order to help remedy the students' fear in communicating 
using the target language.

\section{Problem Statement}

Speaking in English can prove to be a challenging task to the English language learners, especially if they do not have a good command of the language. In the context of this study, a majority of the learners are from the interiors of Sarawak, where English is not spoken except in the English language classrooms. These learners confess to feeling nervous when faced with situations that require them to speak in English both in and out of the classroom setting. They are found to be unable to express themselves effectively in the target language. They also fear the thought of giving presentations in English and some have failed in their speaking assessment despite getting a pass in other components of the English language course.

\section{Objectives}

The main objectives of the study are to identify the types of speaking activity which contribute to communication apprehension among the MDAB students in UiTM Sarawak, and to identify the causes of communication apprehension (CA) among these selected students.

\section{Literature Review}

\subsection{What is Communication Apprehension?}

McCroskey $(1977 a, 1978)$ defined communication apprehension as "an individual's level of fear or anxiety associated with either real or anticipated communication with another person or persons." Meanwhile, Spielberg (1983) defined the term as "the subjective feeling of tension, apprehension, nervousness, and worry associated with an arousal of the automatic nervous system." Despite its negative connotations, anxiety can also be viewed as a positive element. Positive or facilitating anxiety has been found to stimulate learners to pursue language learning despite its negative effects on them. However, negative or debilitating anxiety can interfere with the learning of a second language. Hilgard, Atkinson and Atkinson (1971), as cited in Scovel (1991, p.18), described anxiety as "a psychological construct, commonly described by psychologists as a state of apprehension, a vague fear that is only indirectly associated with an object." Therefore, anxiety is an unclear form of fear. This indicates that the feeling of anxiety towards communicating in English can be overcome with the right approach.

A study by Wan Zumusni et al. (2010) found that the level of communication apprehension among the final year Bachelor of Business Administration students was very high. They discovered that $45 \%$ of the students obtained scores above 80. Their study also revealed that many of the students disliked participating in public speaking and reported feeling tense and nervous when engaging with unfamiliar students in group discussions. This study also highlighted that the students disliked public speaking and viewed it as an activity which incites fear and anxiety. In another related research by Nor Aini and Normazla (2008), the study subjects were found to experience the highest level of communication apprehension when participating in meetings, interpersonal communication and public speaking. Their study also revealed that the major causes of communication apprehension were the personality trait of the students and their inability to pronounce English words correctly. Likewise, Pappamihiel (2002) in her paper wrote that students who came in with fewer language skills tend to be more nervous and anxious about learning the English language. Therefore, anxiety is viewed as a possible stumbling block to the language learning process of these students. Another study conducted in Puerto Rico by Lucas (1984) revealed that only 115 students were found to experience communication anxiety when speaking using their mother tongue, Spanish. However, these students were found to display high communication apprehension (43\%) when speaking in English. A similar study conducted by McCroskey (1984) in Japan found that three-fourths of the samples were classified as having high levels of communication apprehension in both Japanese and English. Finally, in a study conducted by Shameem Rafik-Galea and Siti Yasmin (2006), the researchers found that more than half of their subjects were afraid of using English due to poor proficiency in the language. Their study also found that the subjects had high levels of communication apprehension when using the language to communicate. Similar to Nor Aini and Normazla's (2008) study, they also discovered that one of the main factors of communication apprehension is personality trait.

All of the studies above draw attention to the levels of communication apprehension among learners and point to 
personality trait as one of the main factors of communication apprehension. This current study hopes to identify the types of speaking activities and whether factors such as knowledge of presentation basics and preparation time contribute to communication apprehension among the beginner level English language learners.

\section{Research Methodology}

This study involved 49 pre-diploma students from Part 1, Session 2012/2013 of the Business Management Faculty, Universiti Teknologi MARA (UiTM), Sarawak Campus. They were enrolled in an introductory English course, coded BEL011. The average age of the respondents is 18 years old, who consisted of 40 female and 9 male. These students were specifically selected due to their low level of English language proficiency and the fact that the course (i.e. BEL011) is taught 12 hours a week. The course covers speaking, grammar, writing and reading, whereby speaking contributes to $35 \%$ of the total grade. It runs for one semester, comprising 14 weeks of lectures. The main objective of the course is to remedy the students' weaknesses in the use of English and raise their proficiency level. The speaking component is designed to help the students develop their speaking fluency in various situations.

\section{Instruments}

The questionnaire used in this study was adapted from McCroskey's (1978) Personal Report of Communication Apprehension, as well as Nor Aini and Normazla (2008). The 20-item questionnaire is divided into two parts and two sections. Part 1 consists of the students' demographic data. Meanwhile, Part 2 is divided into two sections, which comprises Section A and Section B. Section A covers the types of speaking activities that may cause communication apprehension, such as discussion, participation in meetings, interpersonal communication and public speaking. Section B encompasses factors that may contribute to communication apprehension, such as knowledge of presentation basics, preparation time and personality. A set of questions were also used in this study to elicit extra information from the participants.

\section{Data Analysis}

The data collected via the questionnaire and semi-structured interview were measured and triangulated. They were then analysed using the Statistical Product and Service Solutions (SPSS) 13 and presented in a tabular form.

\section{Results and Discussions}

The findings from Item $\mathrm{A}$ of the questionnaire (see Table 1) elicited responses regarding the types of communication activity which contribute to communication apprehension among the students. A total of $38.8 \%$ of the students agreed that they dislike participating in group discussions, while $22.4 \%$ strongly agreed, followed by $2.0 \%$ who disagreed and $36.8 \%$ who remained neutral. Moreover, $63.3 \%$ of the students disagreed whereas $10.2 \%$ of them strongly disagreed that they are comfortable participating in group discussions. Meanwhile, a total of $44.9 \%$ of the respondents agreed and $12.2 \%$ strongly agreed that engaging in a group discussion with new people made them tense and nervous. Only $8.2 \%$ of the respondents disagreed while another $8.2 \%$ were undecided.

This is followed by $51 \%$ of the respondents who disagreed and $10.2 \%$ who strongly disagreed that they are not nervous when they have to participate in an English speaking activity. On a total of $14.3 \%$ agreed and $12.2 \%$ strongly agreed that they are not nervous while $12.2 \%$ remained undecided. Next, a total of $30.6 \%$ of the respondents agreed and $36.7 \%$ strongly agreed that they are afraid to express themselves at any speaking activity while 32.7 were undecided.

In addition, $38.8 \%$ of the participants agreed while $10.2 \%$ strongly agreed that communicating during an English speaking activity usually makes them feel uncomfortable. However, $46.9 \%$ of them were neutral whereas $4.1 \%$ expressed their disagreement. Next, $14.3 \%$ of the students strongly disagreed whereas $40.8 \%$ of them disagreed that they are relaxed when answering questions in English. Meanwhile, 24.5\% of the respondents agreed and $20.4 \%$ were undecided on this matter. $51.0 \%$ of the participants agreed that they feel nervous when communicating with a new acquaintance, followed by $6.1 \%$ who strongly agreed, $6.1 \%$ who strongly disagreed, $20.4 \%$ who disagreed and $16.3 \%$ who were undecided. Subsequently, $44.9 \%$ of the respondents agreed and $12.2 \%$ strongly agreed that they are afraid to speak up in a conversation, while $18.4 \%$ disagreed, $8.2 \%$ agreed and $16.3 \%$ were undecided. Interestingly, $65.3 \%$ of the students agreed that they are not uncomfortable when being asked to give a speech, while $34.6 \%$ were neutral. The interview data 
revealed that they have notes to read and refer to when giving a speech, and is it therefore viewed to be not as daunting as public speaking or group discussion.

Table 1. Types of activity which cause communication apprehension

\begin{tabular}{|c|c|c|c|c|c|c|}
\hline Items & $\begin{array}{l}\text { Strongly } \\
\text { Disagree }\end{array}$ & Disagree & Undecided & Agree & $\begin{array}{l}\text { Strongly } \\
\text { Agree }\end{array}$ & Total \\
\hline 1. I dislike participating in group discussions. & $\begin{array}{c}0 \\
(0 \%)\end{array}$ & $\begin{array}{c}2 \\
(2.0 \%)\end{array}$ & $\begin{array}{c}17 \\
(36.8 \%)\end{array}$ & $\begin{array}{c}19 \\
(38.8 \%)\end{array}$ & $\begin{array}{c}11 \\
(22.4 \%)\end{array}$ & 49 \\
\hline $\begin{array}{l}\text { 2. Generally, I am comfortable while } \\
\text { participating in group discussions. }\end{array}$ & $\begin{array}{c}5 \\
(10.2 \%)\end{array}$ & $\begin{array}{c}31 \\
(63.3 \%)\end{array}$ & $\begin{array}{c}13 \\
(26.5 \%)\end{array}$ & $\begin{array}{c}0 \\
0 \% \\
(0 \%)\end{array}$ & $\begin{array}{c}0 \\
0 \% \\
(0 \%)\end{array}$ & 49 \\
\hline $\begin{array}{l}\text { 3. Engaging in a group discussion with new } \\
\text { people makes me tense and nervous. }\end{array}$ & $\begin{array}{c}6 \\
(12.2 \%)\end{array}$ & $\begin{array}{c}13 \\
(26.5 \%)\end{array}$ & $\begin{array}{c}4 \\
(8.2 \%)\end{array}$ & $\begin{array}{c}22 \\
(44.9 \%)\end{array}$ & $\begin{array}{c}4 \\
(8.2 \%)\end{array}$ & 49 \\
\hline $\begin{array}{l}\text { 4. Generally, I am not nervous when I have } \\
\text { to participate in an English speaking } \\
\text { activity. }\end{array}$ & $\begin{array}{c}5 \\
(10.2 \%)\end{array}$ & $\begin{array}{c}25 \\
(51.0 \%)\end{array}$ & $\begin{array}{c}6 \\
(12.2 \%)\end{array}$ & $\begin{array}{c}7 \\
(14.3 \%)\end{array}$ & $\begin{array}{c}6 \\
(12.2 \%)\end{array}$ & 49 \\
\hline $\begin{array}{l}\text { 5. I am afraid to express myself in English at } \\
\text { any English speaking activity. }\end{array}$ & $\begin{array}{c}0 \\
(0 \%)\end{array}$ & $\begin{array}{c}0 \\
0 \% \\
(0 \%)\end{array}$ & $\begin{array}{c}16 \\
(32.7 \%)\end{array}$ & $\begin{array}{c}15 \\
(30.6 \%)\end{array}$ & $\begin{array}{c}18 \\
(36.7 \%)\end{array}$ & 49 \\
\hline $\begin{array}{l}\text { 6. Communicating during an English } \\
\text { speaking activity usually makes me feel } \\
\text { uncomfortable. }\end{array}$ & $\begin{array}{c}0 \\
(0 \%)\end{array}$ & $(4.1 \%)$ & $\begin{array}{c}23 \\
(46.9 \%)\end{array}$ & $\begin{array}{c}19 \\
(38.8 \%)\end{array}$ & $\begin{array}{c}5 \\
(10.2 \%)\end{array}$ & 49 \\
\hline $\begin{array}{l}\text { 7. I am relaxed when answering questions in } \\
\text { English. }\end{array}$ & $\begin{array}{c}7 \\
(14.3 \%) \\
\end{array}$ & $\begin{array}{c}20 \\
(40.8 \%) \\
\end{array}$ & $\begin{array}{c}10 \\
(20.4 \%)\end{array}$ & $\begin{array}{c}12 \\
(24.5 \%)\end{array}$ & $\begin{array}{c}0 \\
(0 \%) \\
\end{array}$ & 49 \\
\hline $\begin{array}{l}\text { 8. While participating in a conversation with } \\
\text { a new acquaintance, I feel very nervous. }\end{array}$ & $\begin{array}{c}3 \\
(6.1 \%)\end{array}$ & $\begin{array}{c}10 \\
(20.4 \%)\end{array}$ & $\begin{array}{c}8 \\
(16.3 \%)\end{array}$ & $\begin{array}{c}25 \\
(51.0 \%)\end{array}$ & $\begin{array}{c}3 \\
(6.1 \%)\end{array}$ & 49 \\
\hline 9. I'm afraid to speak up in conversations. & $\begin{array}{c}4 \\
(8.2 \%)\end{array}$ & $\begin{array}{c}9 \\
(18.4 \%)\end{array}$ & $\begin{array}{c}8 \\
(16.3 \%)\end{array}$ & $\begin{array}{c}22 \\
(44.9 \%)\end{array}$ & $\begin{array}{c}6 \\
(12.2 \%)\end{array}$ & 49 \\
\hline 10. I have no fear of giving a speech. & $\begin{array}{c}0 \\
(0 \%)\end{array}$ & $\begin{array}{c}0 \\
(0 \%)\end{array}$ & $\begin{array}{c}17 \\
(34.7 \%)\end{array}$ & $\begin{array}{c}32 \\
(65.3 \%)\end{array}$ & $\begin{array}{c}0 \\
0 \\
(0 \%)\end{array}$ & 49 \\
\hline
\end{tabular}

The second part of the questionnaire revealed the following findings (see Table 2). In terms of preparation for a presentation, $61.2 \%$ of the students disagreed and $22.4 \%$ strongly disagreed that they prepare carefully before any English language presentation, while $16.3 \%$ were neutral. Next, $59.2 \%$ of the participants disagreed whereas $16.3 \%$ strongly disagreed that they rehearse their speech before any English presentations. Meanwhile, $22.5 \%$ of the students were neutral while $2 \%$ disagreed on this matter. In terms of knowing the format of a presentation, $53.1 \%$ disagreed while $20.4 \%$ strongly disagreed that they know the organization of an individual presentation. Furthermore, $61.2 \%$ of the participants disagreed whereas $20.4 \%$ strongly disagreed that they know how to begin or end their presentations. In addition, $20.4 \%$ of the students were neutral while $6.1 \%$ agreed that they do know how to begin their presentations. Next, $57.1 \%$ disagreed and $20.4 \%$ strongly disagreed that they know how to end a presentation, while $4.1 \%$ agreed and $18.4 \%$ were undecided. In terms of personality trait, $34.7 \%$ of the respondents disagreed that speaking in their mother tongue makes them feel tense; however, $49 \%$ of them agreed that speaking in their first language makes them tense while $16.3 \%$ remained neutral. $51 \%$ of the students agreed that speaking in front of their classmates from the opposite gender makes them nervous, while $22.4 \%$ disagreed and $12.2 \%$ strongly disagreed on this survey item. The rest of the students which comprised $14.3 \%$ were neutral. The findings also revealed that $55.1 \%$ of the participants agreed that they fear of being laughed at when speaking English, followed by $16.3 \%$ who were neutral, $20.4 \%$ who disagreed and $8.2 \%$ who strongly disagreed. When asked during the interview, the participants reported that they are often being laughed at when pronouncing the English words wrongly. Sometimes, their effort to pronounce the words correctly are interpreted as being snobbish by their classmates and this also leads to the embarrassment of being ridiculed during presentations. Subsequently, $34.7 \%$ of the students agreed and $10.2 \%$ strongly agreed that they cannot project their voice clearly during a presentation, while $26.5 \%$ disagreed, $6.1 \%$ strongly disagreed and $22.4 \%$ were undecided. Finally, $40.8 \%$ of the respondents agreed that they cannot pronounce words clearly in English, 8.2\% strongly agreed, while 38.8\% disagreed and $12.2 \%$ were neutral. 
Table 2. Factors causing communication apprehension

\begin{tabular}{|c|c|c|c|c|c|c|}
\hline Items & $\begin{array}{l}\text { Strongly } \\
\text { Disagree }\end{array}$ & Disagree & Undecided & Agree & $\begin{array}{l}\text { Strongly } \\
\text { Agree }\end{array}$ & Total \\
\hline $\begin{array}{l}\text { 1. I always prepare carefully before I do any } \\
\text { English presentation. }\end{array}$ & $\begin{array}{c}11 \\
(22.4 \%)\end{array}$ & $\begin{array}{c}30 \\
(61.2 \%)\end{array}$ & $\begin{array}{c}5 \\
(10.2 \%)\end{array}$ & $\begin{array}{c}3 \\
(6.1 \%)\end{array}$ & $\begin{array}{c}0 \\
(0 \%)\end{array}$ & 49 \\
\hline $\begin{array}{l}\text { 2. I always rehearse my speech before any } \\
\text { English presentation. }\end{array}$ & $\begin{array}{c}8 \\
(16.3 \%) \\
\end{array}$ & $\begin{array}{c}29 \\
(59.2 \%)\end{array}$ & $\begin{array}{c}4 \\
(8.2 \%)\end{array}$ & $\begin{array}{c}7 \\
(14.3 \%) \\
\end{array}$ & $\begin{array}{c}1 \\
(2.0 \%) \\
\end{array}$ & 49 \\
\hline $\begin{array}{l}\text { 3. I know the format/organization of an } \\
\text { individual presentation. }\end{array}$ & $\begin{array}{c}10 \\
(20.4 \%)\end{array}$ & $\begin{array}{c}26 \\
(53.1 \%)\end{array}$ & $\begin{array}{c}10 \\
(20.4 \%)\end{array}$ & $\begin{array}{c}3 \\
(6.1 \%) \\
\end{array}$ & $\begin{array}{c}0 \\
(0 \%) \\
\end{array}$ & 49 \\
\hline $\begin{array}{l}\text { 4. I know several ways to begin my } \\
\text { presentation. }\end{array}$ & $\begin{array}{c}10 \\
(20.4 \%)\end{array}$ & $\begin{array}{c}30 \\
(61.2 \%)\end{array}$ & $\begin{array}{c}7 \\
(14.3 \%) \\
\end{array}$ & $\begin{array}{c}2 \\
(4.1 \%) \\
\end{array}$ & $\begin{array}{c}0 \\
(0 \%) \\
\end{array}$ & 49 \\
\hline 5. I know several ways to end my presentation. & $\begin{array}{c}10 \\
(20.4 \%)\end{array}$ & $\begin{array}{c}28 \\
(57.1 \%)\end{array}$ & $\begin{array}{c}9 \\
(18.4 \%)\end{array}$ & $\begin{array}{c}2 \\
(4.1 \%)\end{array}$ & $\begin{array}{c}0 \\
(0 \%)\end{array}$ & 49 \\
\hline $\begin{array}{l}\text { 6. I feel nervous and tense even when I speak } \\
\text { using my first language. }\end{array}$ & $\begin{array}{c}0 \\
(0 \%)\end{array}$ & $\begin{array}{c}17 \\
(34.7 \%)\end{array}$ & $\begin{array}{c}8 \\
(16.3 \%)\end{array}$ & $\begin{array}{c}24 \\
(49 \%)\end{array}$ & $\begin{array}{c}0 \\
(0 \%) \\
\end{array}$ & 49 \\
\hline $\begin{array}{l}\text { 7. I feel uncomfortable talking in front of my } \\
\text { classmates from the different gender. }\end{array}$ & $\begin{array}{c}0 \\
(0 \%)\end{array}$ & $\begin{array}{c}17 \\
(34.7 \%)\end{array}$ & $\begin{array}{c}7 \\
(14.3 \%) \\
\end{array}$ & $\begin{array}{c}25 \\
(51 \%)\end{array}$ & $\begin{array}{c}0 \\
(0 \%) \\
\end{array}$ & 49 \\
\hline $\begin{array}{l}\text { 8. Because I am always laughed at whenever I } \\
\text { speak in English, I do not like to use the } \\
\text { language. }\end{array}$ & $\begin{array}{c}6 \\
(12.2 \%)\end{array}$ & $\begin{array}{c}11 \\
(22.4 \%)\end{array}$ & $\begin{array}{c}8 \\
(16.3 \%)\end{array}$ & $\begin{array}{c}24 \\
(51 \%)\end{array}$ & $\begin{array}{c}0 \\
(0 \%)\end{array}$ & 49 \\
\hline $\begin{array}{l}\text { 9. I think I cannot project my voice clearly } \\
\text { during a presentation. }\end{array}$ & $\begin{array}{c}3 \\
(6.1 \%)\end{array}$ & $\begin{array}{c}13 \\
(26.5 \%)\end{array}$ & $\begin{array}{c}11 \\
(22.4 \%)\end{array}$ & $\begin{array}{c}17 \\
(34.7 \%)\end{array}$ & $\begin{array}{c}5 \\
(10.2 \%)\end{array}$ & 49 \\
\hline $\begin{array}{l}\text { 10. I think I cannot pronounce my words in } \\
\text { English clearly and correctly. }\end{array}$ & $\begin{array}{c}0 \\
(0 \%)\end{array}$ & $\begin{array}{c}18 \\
(38.8 \%)\end{array}$ & $\begin{array}{c}6 \\
(12.2 \%)\end{array}$ & $\begin{array}{c}20 \\
(40.8 \%)\end{array}$ & $\begin{array}{c}4 \\
(8.2 \%)\end{array}$ & 49 \\
\hline
\end{tabular}

\section{Conclusion}

Communication apprehension and the causes of communication apprehension among pre-university students in learning English as a second language should be addressed at the beginner level of English language classes. Based on the findings, the learners should be taught basic presentation skills, such as how to structure an individual presentation, ways to begin and end a presentation, as well as verbal and non-verbal communication skills. Additionally, implementing activities which focus on improving students' pronunciation may help alleviate their fear of being unable to pronounce unfamiliar words. Furthermore, using fun speaking activities, such as songs, poems or board games, may be able to encourage the students to speak, and thus, this could lower their anxiety levels.

\section{References}

Azmi, S., Wasif, S. G. (2011). Communication Apprehension among Malaysian Pharmacy Students: A Pilot Study. Indian Journal of Pharmaceutical Education and Research. Jan-Mar 2011. Vol 45. Issue 1.

McCroskey, J. C. (1977). Oral communication apprehension: A summary of recent theory and research. Human Communication \& Research, 4, 78-96.

McCroskey, J. C. (1978). Validity of the PRCA as an index of oral communication apprehension. Communication Monographs, 45, 192203.

McCroskey, J. C. (1984). The communication apprehension perspective. In J. A. Daly \& J. C. McCroskey (Eds.)

McCroskey, J. C. (1984). The communication apprehension perspective. In J. A. Daly \& J. C. McCroskey (Eds.). Avoiding communication: Shyness, reticence, and communication apprehension (13-38). Beverly Hills, CA: Sage Publications, Inc.

Nor Aini \& Normazla (2008). Communication Apprehension in a Language Classroom. In Haliza Harun (Eds.). Issues on English as a Second Language Pedagogy: A Research Based Perspective. Penerbit USIM.

Pappamihiel, N. E. (2002). English As A Second Language Students And English Language Anxiety. Issues In The Mainstream Classroom. Proquest Education Journal, 36(3), 327-355. Pearson, J. 1983. Interpersonal communication. Glenview, IL: ScottForesman.

Scovel, T. (1991). The effect of affect on foreign language learning: A review of the anxiety research. In E. K. Horwitz \& D. J. Young (Eds.), Language anxiety: From theory and research to classroom implications (pp. 15-23). Englewood Cliffs, NJ: Prentice Hall.

Shameem Rafik-Galea \& Siti Yasmin Mohd. Zain (2006). Communication Apprehension and Language Choice in Communicating. In Kamisah Afiffin, Mohd. Rozaidi Ismail,

Ngo Kea Leang \& Roslina Abdul Aziz (eds.). English in the Malaysian Context. Shah Alam. UiTM UPENA Press.

Spielberg, C. D. (1983). Manual for the State-Trait Anxiety Inventory (STAI). Consulting Psychologists Press, Palo Alto, CA. 